This item was submitted to Loughborough's Research Repository by the author.

Items in Figshare are protected by copyright, with all rights reserved, unless otherwise indicated.

\title{
Numerical dosimetry of CDMAVGSM, DCS/PCS and 3G signal jammers
}

PLEASE CITE THE PUBLISHED VERSION

http://dx.doi.org/10.1049/iet-map.2014.0713

\section{PUBLISHER}

(c) The Institution of Engineering and Technology

\section{VERSION}

AM (Accepted Manuscript)

\section{PUBLISHER STATEMENT}

This work is made available according to the conditions of the Creative Commons Attribution-NonCommercialNoDerivatives 4.0 International (CC BY-NC-ND 4.0) licence. Full details of this licence are available at: https://creativecommons.org/licenses/by-nc-nd/4.0/

\section{LICENCE}

CC BY-NC-ND 4.0

\section{REPOSITORY RECORD}

Yahya, Salah I., W.G. Whittow, and Yazen A. Khaleel. 2019. "Numerical Dosimetry of CDMA/GSM, DCS/PCS and 3G Signal Jammers". figshare. https://hdl.handle.net/2134/21838. 


\section{Numerical Dosimetry of CDMA/GSM, DCS/PCS and 3G Signal Jammers}

${ }^{1}$ Salah I. Yahya, ${ }^{2 *}$ Will G. Whittow and ${ }^{3}$ Yazen A. Khaleel

${ }^{1}$ Associate Prof., Department of Software Engineering, Faculty of Engineering, Koya University

Daniel Mitterrand Boulevard, Koya KOY45, Kurdistan Region - F.R. Iraq

salah.ismaeel@koyauniversity.org

${ }^{2}$ Senior Lecturer,

School of Electronic, Electrical and Systems Engineering, Loughborough University, UK

w.g.whittow@lboro.ac.uk

${ }^{3}$ Assistant Prof.,

Department of Software Engineering, Faculty of Engineering, Koya University

Daniel Mitterrand Boulevard, Koya KOY45, Kurdistan Region - F.R. Iraq

yazen.adnan@koyauniversity.org

*corresponding author 


\begin{abstract}
In this study, numerical dosimetry of a code division multiple access (CDMA)/global system for mobile communication (GSM), digital cellular service (DCS)/personal communications service (PCS) and third generation (3G) signal jammer working with three antennas is presented. The simultaneous exposure of three anatomically full human body phantoms of different ages and genders to portable jammer electromagnetic waves (EM) at 900, 1800 and $2100 \mathrm{MHz}$, are numerically modelled using a highresolution finite-difference time-domain gridding; solved by a full-wave three-dimensional EM simulation software on a high-performance workstation machine. The average specific absorption rate (SAR) in the whole human body and the peak spatial SAR averaged over $1 \mathrm{~g}$ induced in the biological tissues of the head and torso were evaluated at different distances from the signal jammer above a ground consisting of concrete and soil layers. The maximum radiated power by the signal jammer at different distances in front of the human body was calculated for safe exposure in compliance with the institute of electrical and electronics engineers (IEEE)/American national standards institute (ANSI)/federal communications commission (FCC) standard limits.
\end{abstract}

Keywords - Anatomical phantom, Antenna, FDTD, Electromagnetic wave absorption, Numerical dosimetry, SAR, SEMCAD X, Signal jammer, Tesla GPU.

\title{
1. INTRODUCTION
}

Since the 1991 launch of second-generation commercial cellular communication in Finland, there has been an ongoing debate on the possible human hazard of exposure to the electromagnetic (EM) waves from mobile handset antennas [1]-[9]. Owing to the many new emerging wireless connectivity standards/technologies, there is also a concern about the possible human hazard of exposure to radio frequency (RF) waves from wireless technology used in home and office environments, e.g., digital enhanced cordless telecommunications (DECT), Bluetooth and wireless local area network (WLAN) [10]. These possible hazards have been evaluated by computing the specific absorption rate (SAR) induced in the human head/body tissues in terms of the peak spatial-average SAR over $1 \mathrm{~g}(1 \mathrm{~g} \mathrm{SAR})$ or $10 \mathrm{~g}(10 \mathrm{~g}$ 
SAR) in the head or the averaged SAR in the whole body. The SAR exposure limits are set by different standards in different countries [11]-[15]. Table 1 lists the SAR limits recommended for nonoccupational users in different countries and regions.

Table 1. SAR limits for nonoccupational/unaware users in different countries and regions.

\begin{tabular}{|l|c|c|c|c|}
\hline & USA & Europe & Australia & Japan \\
\hline Organization/body & IEEE/ANSI/FCC & ICNIRP & ACA & TTC/MPTC \\
\hline Measurement method & C95.1 & EN50360 & ARPANSA & ARIB \\
\hline Whole-body averaged SAR & $0.08 \mathrm{~W} / \mathrm{kg}$ & $0.08 \mathrm{~W} / \mathrm{kg}$ & $0.08 \mathrm{~W} / \mathrm{kg}$ & $0.04 \mathrm{~W} / \mathrm{kg}$ \\
\hline Peak spatial-average SAR & $1.6 \mathrm{~W} / \mathrm{kg}$ & $2 \mathrm{~W} / \mathrm{kg}$ & $2 \mathrm{~W} / \mathrm{kg}$ & $2 \mathrm{~W} / \mathrm{kg}$ \\
\hline Averaging mass & $1 \mathrm{~g} \mathrm{cube}$ & $10 \mathrm{~g}$ cube & $10 \mathrm{~g} \mathrm{cube}$ & $10 \mathrm{~g} \mathrm{cube}$ \\
\hline Averaging time & $30 \mathrm{~min}$ & $6 \mathrm{~min}$ & $6 \mathrm{~min}$ & $6 \mathrm{~min}$ \\
\hline Reference & {$[11]$} & {$[12],[13]$} & {$[14]$} & {$[15]$} \\
\hline
\end{tabular}

IEEE: Institute of electrical and electronics engineers.

ANSI: American national standards institute.

FCC: Federal communications commission.

ICNIRP: International commission on non-ionizing radiation.

ACA: Australian communications authority.

TTC: Telecommunication technology committee.

MPTC: Ministry of posts and telecommunications.

ARPANSA: Australian radiation protection and nuclear safety agency.

ARIB: Association of radio industries and businesses.

In June 2003, the radio-communication sector of the International Telecommunication Union (ITUR) [16] approved the following bands for the terrestrial mobile communication IMT-2000: 806-960 MHz, 1710-2025 MHz, 2110-2200 MHz, and 2500-2690 MHz. In the United States, Canada, and many other countries in America, global system for mobile communication (GSM) 850 and GSM 1900/personal communications service (PCS) bands are used, whereas in Europe, the Middle East, Africa, and most of Asia, extended (E)-GSM 900, GSM 1800/digital cellular service (DCS), and universal mobile telecommunications system (UMTS)/wideband code division multiple access (WCDMA) 2000 are used.

Owing to the wide usage of cellular communication in addition to other wireless communicationsi.e., Bluetooth uses IEEE-Std. 802.15.1-200X [17], Wi-Fi uses IEEE-Std. 802.11b/g/n [18], and worldwide interoperability for microwave access (WiMAX) uses IEEE-Std. 802.16e-2005 [19]—mobile phone signal jamming devices are used in military applications to interrupt communication by criminals 
and terrorists as well as in civil applications to block cellular communication in seminar/meeting halls, classrooms, theatres, etc.

Commercial mobile phone jamming systems for civil applications are available in various formsi.e., portable and desktop. Portable jammers actually work with 3-8 different frequency bands, may include WiFI, WiMax, and Global Positioning System (GPS) signals, and have total output power of 3-4 W-i.e., single-antenna output power in the range of 0.3-1.0 W. Desktop jammers may work with 6-12 different frequency bands and have a total output power of 60-80 W-i.e., single-antenna output power in the range of 1-3 W, depending on application and coverage area [20]. However, jamming systems for military applications use high power of up to $250 \mathrm{~W}$ (20-25 W/antenna) - e.g., vehicle mobile phone jammer, remotely detonated improvised explosive device (IED) jamming system, and backpack jamming system. Although the jammer device geometry considered for simulation in this paper is portable type, the dosimetry of other geometries with higher power levels — desktop and military devices — can be obtained by scaling the results.

Jamming devices use different techniques and strategies [21] - e.g., continuous-wave (CW) and pulse jamming. In this paper, a CW jamming device is considered for the numerical dosimetry. Nevertheless, other devices may have a duty cycle, and thus the results concerning the dosimetry and output power must be reduced by the equivalent value.

Because mobile phone signal jammers actively broadcast radio signals, some countries-e.g., United States, Canada, Australia, Sweden-have outlawed the manufacture, sale, and/or use of such jammers except by federal law-enforcement agencies and in jails [22]-[25]. In the United Kingdom, it is illegal to use mobile phone signal jammers; however, they are legal to own, and since the end of 2012, the installation and use of jammers in jails has been legal [26]. In spite of this, mobile phone signal jammer devices are available worldwide in electronic markets and used in different applications.

Owing to the abovementioned reasons, and because the safety of mobile phone signal jammers has not been previously assessed, this paper uses the mobile phone safety limits to assess jammer safety, and the $1 \mathrm{~g}$ SAR results relating to the IEEE/ANSI/FCC standards will be presented. In all cases, the $1 \mathrm{~g}$ SAR 
limits are stricter than the $10 \mathrm{~g}$ SAR limits and the $2100 \mathrm{MHz}$ band have been shown to be 1.88 times stricter than the ICNIRP $10 \mathrm{~g}$ limits [27].

No studies in the literature have investigated the possible EM radiation hazard of mobile phone signal jammers. In this paper, an accurate numerical dosimetry of a commercially available CDMA/GSM, DCS/PCS, and 3G signal jammer module working with three antennas is modelled using a finitedifference time-domain (FDTD)-based solver. The three antennas were modelled to work at 900, 1800, and $2100 \mathrm{MHz}$ simultaneously. The portable signal jammer is modelled while facing three different anatomical human body phantoms and positioned at a distance of $120 \mathrm{~cm}$ above a $3 \times 3 \mathrm{~m}^{2}$ ground of concrete and soil layers. A high-performance workstation machine with active accelerator hardware was used to achieve high-resolution FDTD gridding.

The remainder of the paper is organized as follows: in Section 2, the numerical approach and computational requirements are described. In Section 3, the numerical models are styled. In Section 4, the FDTD gridding and simulation parameter settings are explained. In Section 5, the SAR due to multiple sources is projected. In Section 6, the numerical results are presented and discussed. Finally, Section 7 concludes the paper.

\section{NUMERICAL APPROACH AND COMPUTATIONAL REQUIREMENT}

The FDTD method proposed by Kane Yee in 1966 [28] was used in this paper to solve the numerical models. The FDTD method employs finite differences as approximations to both the spatial and temporal derivatives that appear in Maxwell's equations (specifically, Ampere's and Faraday's laws) [29]. Although the FDTD method can solve complicated problems, it is generally considered to be computationally expensive. A licensed SEMCAD X® Aletsch version 14.8.6, commercially available from Schmid \& Partner Engineering AG (SPEAG) [30], was selected and used to simulate and solve the numerical dosimetry of the mobile phone signal jammer. A high-performance workstation machine (hp® Z420) [31] with an NVIDIA® Quadro K2000 graphics card is used, which is accelerated by a Tesla® graphics processing unit $(\mathrm{GPU} \circledast)$ K20 [32] using the NVIDIA® compute unified device architecture 
(CUDA) driver and based on the NVIDIA $®$ Kepler $^{\mathrm{TM}}$ Architecture. The hp® Z420 machine is working with 6 processors (Intel® Xeon® CPU E5-1620 v2 @ 3.70 GHz 15 MB 1866) and 32 GB memory size. The Tesla® GPU® K20 card is working with 208 GB/s memory bandwidth and 5 GB memory size. The hp® Z420 with the assistance GPU® $\mathrm{K} 20$ demonstrated the ability to process a problem size of approximately 100 Mcell with a speed of 1300 Mcell/s. For a problem size of more than 100 Mcell, the processing speed decreases to approximately $350 \mathrm{Mcell} / \mathrm{s}$. Note that the maximum processing speed of the workstation without the accelerator is only $50 \mathrm{Mcell} / \mathrm{s}$.

\section{NUMERICAL MODELS}

\section{Signal Jammer Numerical Model}

The numerical modelling of internal and external antennas for mobile phones with different form factors was investigated in [7], [33]-[34]. The design and performance parameters presented in [7] were considered in this paper to model the signal jammer. A portable mobile phone signal jammer working with three omnidirectional antennas covering three bands-CDMA/GSM: 850-960 MHz; DCS/PCS: 1805-1990 MHz; 3G: 2110-2170 MHz, available commercially [20] under different brands-is adopted in this paper for the numerical dosimetry. The jammer device is modelled numerically with maximum dimensions of $110 \times 60 \times 30 \mathrm{~mm}^{3}$ (length $\times$ width $\times$ thickness) and multilayer printed circuit board $(\mathrm{PCB})$ dimensions of $108 \times 58 \times 1 \mathrm{~mm}^{3}$. The considered electromechanical parts of the jammer device model are the antenna, multilayer PCB, housing, antenna cover, and battery. The jammer housing material was defined with electrical permittivity $\varepsilon_{r}=3.5$ and electrical conductivity $\sigma=0.02 \mathrm{~S} / \mathrm{m}$, the antenna cover materials were defined with $\varepsilon_{r}=2.5$ and $\sigma=0.003 \mathrm{~S} / \mathrm{m}$, and the PCB material was defined with $\varepsilon_{r}=4.5$ and $\sigma=0.07 \mathrm{~S} / \mathrm{m}[7]$

Fig. 1 shows the computer-aided design (CAD) model of the adopted jammer device with three omnidirectional antennas working at 900, 1800, and $2100 \mathrm{MHz}$ simultaneously. A short-whip antenna top-loaded with a small cylinder suggested in [7] was used to model the jammer's three antennas with a structure shown in Fig. 2. A matching lumped element of $18.3 \mathrm{nH}$ at $900 \mathrm{MHz}$ and a $5 \mathrm{nH}$ at $2100 \mathrm{MHz}$ 
were added after the source to tune the antenna. No lumped element was needed to tune the antenna at $1800 \mathrm{MHz}$. Although these lumped elements showed a degradation of 10-20\% in antenna radiation efficiency, the total efficiency and the total isotropic sensitivity (TIS) are within the range of wireless communication [7], [35]. The TIS is a measure of the device's receiver performance. It can be measured in a reverberation chamber with the definition formula given in [36], but SEMCAD X® has the ability to compute the TIS based on standards set forth by the cellular telephone industries association (CTIA) [37].
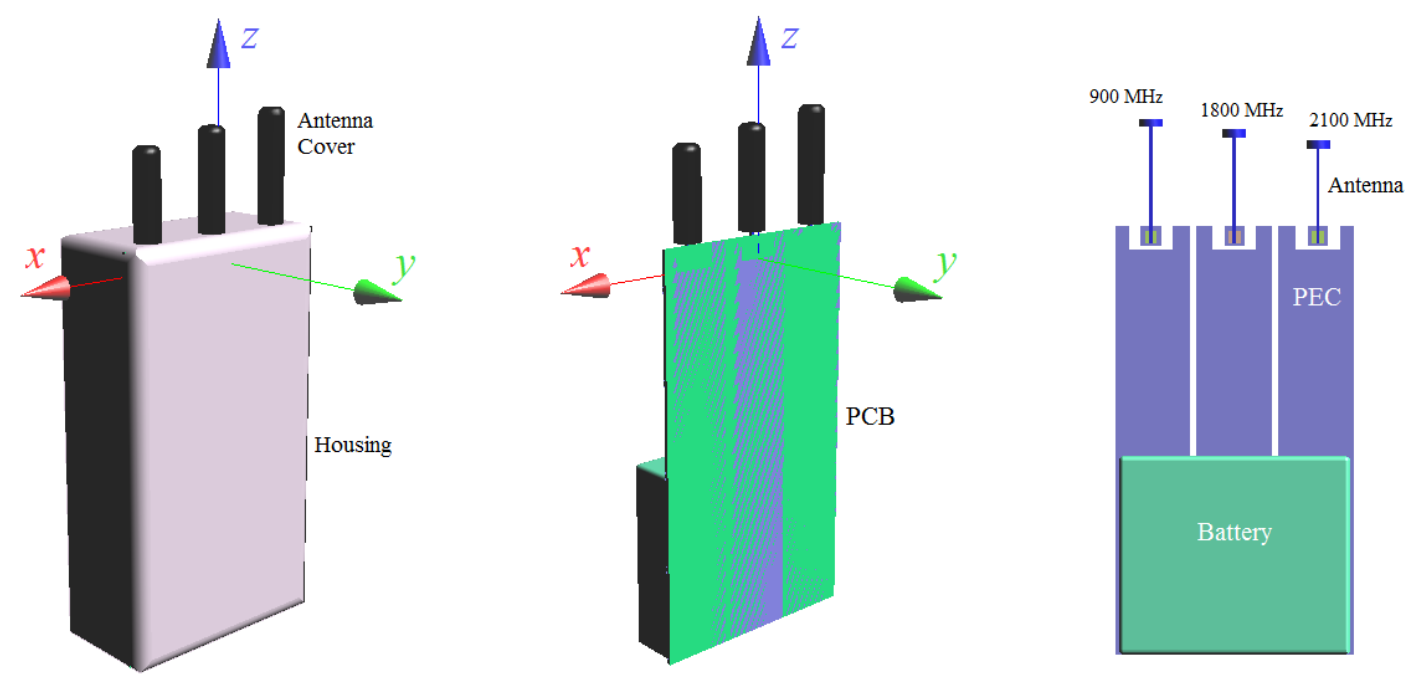

Fig. 1. CAD representation of the portable jammer showing different components and parts from different views.

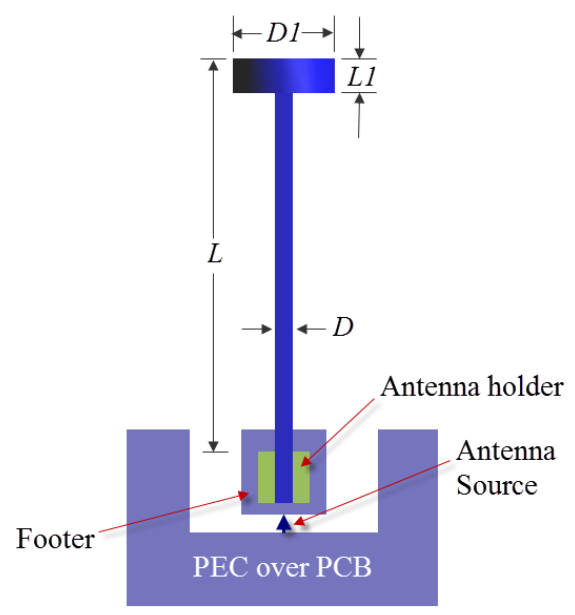

Fig. 2. Short-whip loaded monopole antenna structure including the holder and footer with dimensions. 
Table 2 lists the physical and performance parameters of the jammer's three antennas. Fig. 3 shows the normalized electrical field radiation beam pattern at 900, 1800, and $2100 \mathrm{MHz}$. The radiation beam patterns at 900,1800, and $2100 \mathrm{MHz}$ coincide with the patterns of the typical candy-bar mobile phone with the same external antenna type working at the same frequencies and presented in [7]. The nonomnidirectionality and asymmetry shown in the radiation beam patterns depend on the antenna attachment position to the PCB, antenna position with respect to other antennas, and the perfect electrical conductor (PEC) layer with the given dimensions, and they increase as the frequency increases.

Table 2. Physical and performance parameters of the portable jammer's three antennas

\begin{tabular}{|c|c|c|c|}
\hline \multicolumn{4}{|c|}{ Physical parameters } \\
\hline & Antenna 1 & Antenna 2 & Antenna 3 \\
\hline Frequency $(\mathrm{MHz})$ & 900 & 1800 & 2100 \\
\hline Total physical length (L), mm & 27.7 & 24.4 & 22.2 \\
\hline Diameter (D), mm & 1 & 1 & 1 \\
\hline Antenna load radius (D1), $\mathrm{mm}$ & 6 & 6 & 6 \\
\hline Antenna load height (L1), mm & 2 & 2 & 2 \\
\hline \multicolumn{4}{|c|}{ Performance parameters } \\
\hline & Antenna 1 & Antenna 2 & Antenna 3 \\
\hline $\mathrm{S} 11(\mathrm{~dB})$ & -42.50 & -21.06 & -14.00 \\
\hline Standing Wave Ratio (SWR) & 1.02 & 1.19 & 1.48 \\
\hline Total Efficiency $(\%)$ & 61.2 & 75.4 & 59.0 \\
\hline Gain $(\mathrm{dBi})$ & 2.03 & 3.15 & 4.63 \\
\hline TIS $(\mathrm{dBm})$ & -103.9 & -104.8 & -103.7 \\
\hline
\end{tabular}

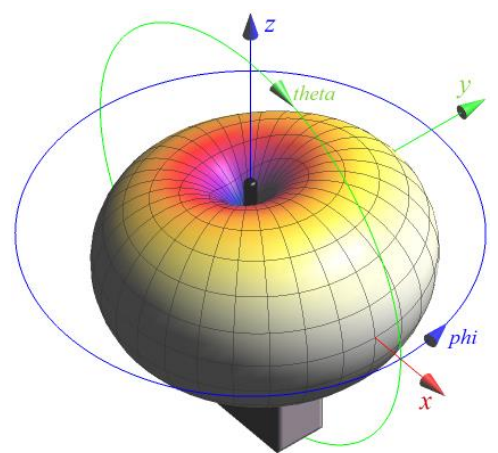

(a)

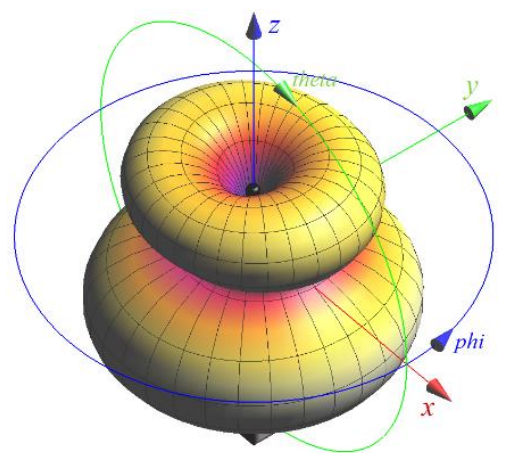

(b)

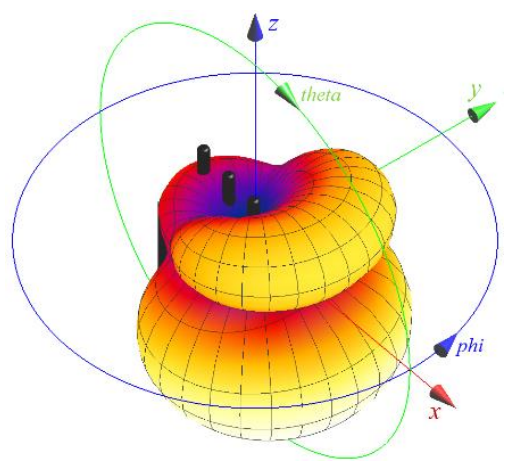

(c)

$\begin{array}{llllll}0 & -4 & -8 & -12 & -16 & -20 \mathrm{~dB}\end{array}$

Fig. 3. Normalized 3D-electrical radiation beam pattern at; (a) $900 \mathrm{MHz}$, (b) $1800 \mathrm{MHz}$, and (c) $2100 \mathrm{MHz}$. 


\section{Anatomical Human Body Numerical Models}

To investigate the EM wave interaction of the mobile phone signal jammer with a human and to achieve a numerical dosimetry of the jammer exposure, three licensed anatomical human body phantoms available with SPEAG [30] were used to simulate the human presence in front of the portable jammer and compute the induced SAR in the body. The three anatomical phantoms are; Eratha, Ella, and Visible Human (VH). Table 3 lists the specifications of the three phantoms. Their material permittivity and electrical conductivity were set according to the material database available with SEMCAD X®. Fig. 4 shows the three anatomical phantoms with different tissues.

Table 3. Specifications of the anatomical phantoms used for the numerical dosimetry.

\begin{tabular}{|c|c|c|c|}
\hline Numerical model name & Eratha & Ella & VH \\
\hline Feature & Whole body & Whole body & Whole body \\
\hline Version & 4 & 2 & 2 \\
\hline Height $(\mathrm{m})$ & 1.360 & 1.630 & 1.878 \\
\hline *Weight $(\mathrm{kg})$ & 30.9 & 58 & 102 \\
\hline Race & Caucasian & Caucasian & Caucasian \\
\hline Age & 8 & 26 & 38 \\
\hline Sex & Female & Female & Male \\
\hline Slice separation & $2 \mathrm{~mm}$ & $2 \mathrm{~mm}$ & $2 \mathrm{~mm}$ \\
\hline No of tissues & 75 & 76 & 125 \\
\hline
\end{tabular}

*The weight is calculated based on the density $\left(\mathrm{kg} / \mathrm{m}^{3}\right)$ of each tissue defined according to materials database available from SPEAG [30].

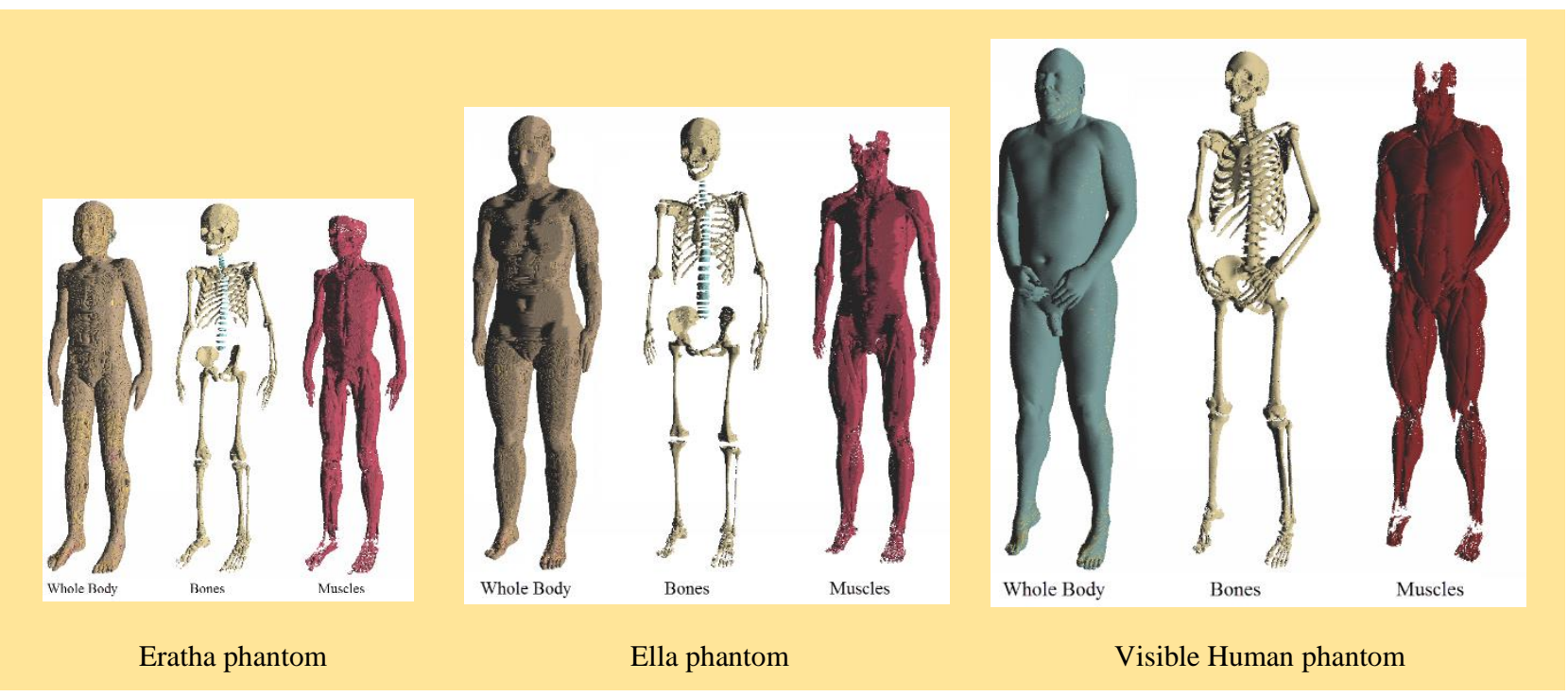

Fig. 4. Three anatomical phantoms showing the whole body, bone tissue, and muscle tissue. 


\section{Ground Numerical Model}

During the numerical dosimetry, the mobile phone signal jammer model was placed in an open field above a $300 \times 300 \mathrm{~cm}^{2}$ two-layer ground at a height of $h=120 \mathrm{~cm}$. The ground layers consists of 10cm-thick condensed concrete with $\varepsilon_{r}=6.0$ and $\sigma=0.02 \mathrm{~S} / \mathrm{m}$ [38] positioned above a 30-cm-thick soil layer with $\varepsilon_{r}=4.0$ and $\sigma=0.01 \mathrm{~S} / \mathrm{m}$ [39]. Fig. 5 shows a perspective view of a complete scenario model with the Ella phantom.

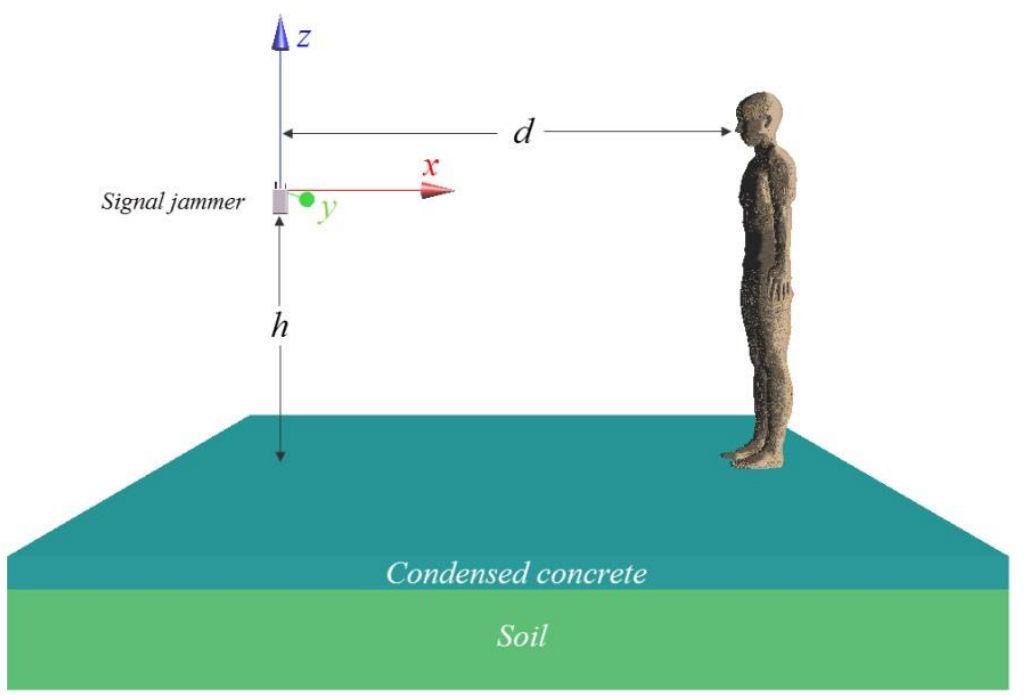

Fig. 5. Perspective view of a complete scenario model showing the portable signal jammer at $d=200 \mathrm{~cm}$ from the Ella phantom at $h=120 \mathrm{~cm}$ above the ground of condensed concrete and soil layers.

\section{FDTD-GRID GENERATION AND SIMULATION PARAMETERS}

The following three scenarios were considered to achieve the numerical dosimetry of the portable jammer:

a) Portable jammer at $d=20,50,100$, and $200 \mathrm{~cm}$ from the Eratha phantom.

b) Portable jammer at $d=20,50,100$, and $200 \mathrm{~cm}$ from the Ella phantom.

c) Portable jammer at $d=20,50,100$, and $200 \mathrm{~cm}$ from the VH phantom. 
The distance between the jammer and the body phantom $(d)$ is calculated between the origin point at the source of the $1800 \mathrm{MHz}$ antenna and the nearest point of the body phantom. Instead of examining the numerical dosimetry of the portable jammer at different positions above the ground, a fixed position with height of $h=120 \mathrm{~cm}$ is used in front of three anatomical phantoms of different ages/sizes and genders (see Fig. 6). In this work, we have made the assumption that $120 \mathrm{~cm}$ is the realistic height of the portable jammer above the ground when used as a handheld or a desktop, and the person will not be within $20 \mathrm{~cm}$ of the jammer; thus, we have considered only long distances.

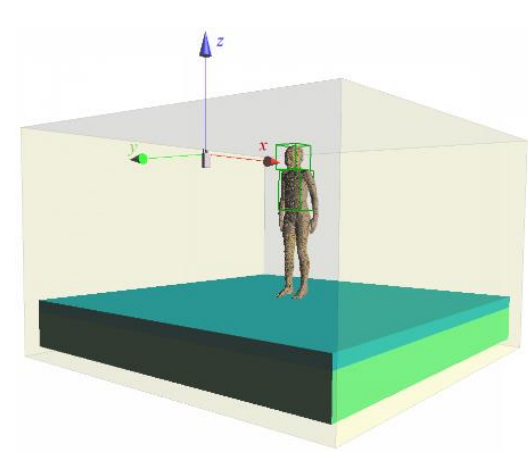

(a)

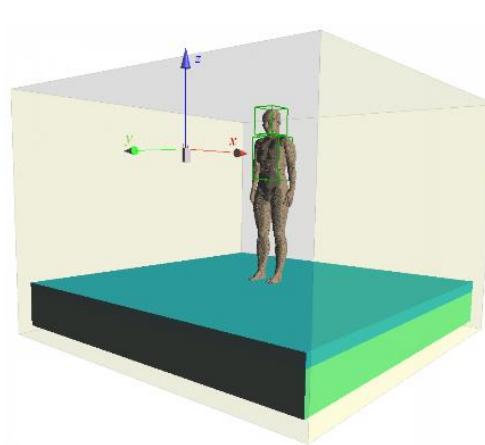

(b)

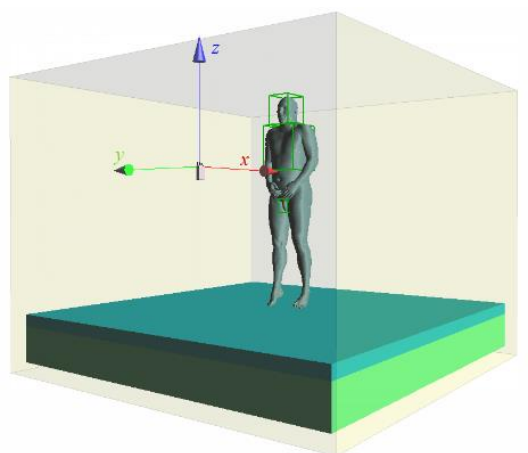

(c)

Fig. 6. Three scenario models with boundaries; (a) Eratha in front of the Jammer at a $100 \mathrm{~cm}$ distance, (b) Ella in front of the jammer at a $100 \mathrm{~cm}$ distance, and (c) VH in front of the jammer at a $100 \mathrm{~cm}$ distance.

To align the mobile phone signal jammer components to the FDTD grid accurately, a general setting with a baseline resolution of $0.25 \mathrm{~mm}$, grading ratio of 1.2 , and grading relaxation of 10 were chosen, where a local setting with a scale of 0.1 for the jammer components and 0.15 for the body tissues were chosen in all $x, y$, and $z$ directions. The most crucial parts with respect to grid resolution are the antenna and the PCB with its thin PEC ground layers (110- $\mu$ m thickness). The simulation space dimensions are $317.5 \times 318 \times 194.6 \mathrm{~cm}^{3}$ for the Eratha phantom scenario, $317.5 \times 318 \times 221.6 \mathrm{~cm}^{3}$ for the Ella phantom scenario, and $317.5 \times 318 \times 245.8 \mathrm{~cm}^{3}$ for the $\mathrm{VH}$ phantom scenario. 
The numerical computation with SEMCAD X® assumes a steady-state voltage at 900, 1800, and 2100 MHz. A feed point of a 50- $\Omega$ voltage source with a 1-mm gap was set for the antenna at $1800 \mathrm{MHz}$, whereas sources with $0.5-\mathrm{mm}$ gaps and another $0.5-\mathrm{mm}$ gap for the match lumped element were set for antennas at 900 and $2100 \mathrm{MHz}$. A transient excitation of 20 periods was set as a guarantee to achieve a steady state. The absorbing boundary conditions were set as a uniaxial perfectly matched layer mode with a high strength thickness, where the minimum level of absorption at the outer boundary is $>95 \%$.

The numbers of FDTD grid cells required for simulating the Eratha, Ella, and VH scenarios were; 252.118, 309.778, and 365.282 Mcell, respectively, at all distances. Although reasonable results have been obtained with only four cells per wavelength [40], the maximum step for the background setting was $14 \mathrm{~mm}$ in all scenarios and at all frequencies. This setting ensures at least 10 cell per wavelength at 2100 MHz and 23 cell per wavelength at $900 \mathrm{MHz}$. The idea behind keeping the same gridding maximum step-i.e., $14 \mathrm{~mm}$, at 900, 1800, and $2100 \mathrm{MHz}$ - is to obtain the same number of FDTD cells. This is essential to evaluate the $1 \mathrm{~g}$ SAR owing to the combined local SAR of the three frequencies [30]. The numerical computations required a minimum processing time of 03:49:00 (hh:mm:ss) and a maximum of 12:41:51. The processing time is mainly dependent on the grid-cell size and frequency.

\section{SAR DUE TO MULTIPLE SOURCES}

The SAR in tissue can be determined by means of E-field measurement [11]-[15]:

$$
S A R=\frac{\sigma E_{r m s}^{2}}{\rho}
$$

SAR is measured in $[\mathrm{W} / \mathrm{kg}], \rho$ is the mass density of the tissue $\left[\mathrm{kg} / \mathrm{m}^{3}\right]$ and $E_{\mathrm{rms}}$ is the root mean square (RMS) value of the electric field [V/m]. For multiple field exposure situations-e.g., different frequency field sources at radio frequencies from $100 \mathrm{kHz}$ to $300 \mathrm{GHz}$ - the maximum permissible exposure (MPE), in terms of RMS electric $(E)$ and magnetic $(H)$ field strengths and the equivalent plane-wave free space power densities (S), are presented in IEEE Std C95.1-2005 [11]. According to this standard technique, 
compliance is determined by summing the percentages of the applicable MPEs that each frequency field represents and ensuring that this sum does not exceed 100\%. However, the SAR induced in the head due to the total electric fields of multiple independent sources of CW signals over the frequency range 0.5 to 4 GHz was examined by Whittow et al. [41]. For multiple sources with different frequencies, the RMS value of the total electric field $E_{\text {tot }}$ at each point in space can be expressed as a sum of the RMS values of the fields due to each source taken separately. The combined local SAR is then found by calculating the RMS of $E_{\text {tot }}^{2}[41]$

$$
S A R=\frac{\sigma}{N \rho} \sum_{1}^{N} E_{\text {tot }}^{2}
$$

where $N$ is the number of points in a period of the combined electric field. The total local combined SAR of three different frequencies at a point is always equal to $\mathrm{SAR}_{f 1}+\mathrm{SAR}_{f 2}+\mathrm{SAR}_{f 3}$. It was shown in [41] that in the case of two sources, the whole-head averaged SAR will always be $\mathrm{SAR}_{f 1}+\mathrm{SAR}_{f 2}$; therefore, the total heating in the head will increase with multiple sources. This is applicable for the whole-body averaged SAR computation as well.

The maximum combined $1 \mathrm{~g}(10 \mathrm{~g})$ SAR occurs when the three independent sources cause a maximum in the same location in the head/torso and will equal $1 \mathrm{~g}(10 \mathrm{~g}) \mathrm{SAR}_{f 1}+1 \mathrm{~g}(10 \mathrm{~g}) \mathrm{SAR}_{f 2}+1 \mathrm{~g}(10 \mathrm{~g}) \mathrm{SAR}_{f 3}$ for the three frequencies. The minimum $1 \mathrm{~g}(10 \mathrm{~g}) \mathrm{SAR}$ is the maximum value of $\left(\mathrm{SAR}_{f 1}\right.$ or $\mathrm{SAR}_{f 2}$ or $\mathrm{SAR}_{f 1}$ ). In practice, the combined SAR will always be greater than this, because the other frequencies will not produce zero SAR values at the location of highest SAR. The worst scenario we can expect for the total combined averaged spatial peak $1 \mathrm{~g}(10 \mathrm{~g})$ SAR is equal to the algebraic sum of the individual peak SAR at each frequency. SEMCAD X® has the ability to calculate the total whole-body averaged SAR and the total $1 \mathrm{~g}(10 \mathrm{~g})$ SAR due to the multiple sources. It stores the electric fields at each Yee cell interface at different frequencies. Therefore, the SAR at each point in the body can be calculated in the postprocessing from the individual frequencies. The final step is to then calculate the maximum $1 \mathrm{~g}$ SAR from the local SAR at each point. 


\section{NUMERICAL RESULTS AND DISCUSSION}

Although the jammer antenna shows an almost omnidirectional electrical radiation field pattern at 900 $\mathrm{MHz}$, more field intensity was given in the $x$-direction for the three adopted frequencies. As the worst case, the human phantoms were positioned in the $x$-direction. The numerical dosimetry includes computation of the following:

1. 1g SAR in the head for the Eratha, Ella, and VH phantoms.

2. 1g SAR in the torso for the Eratha, Ella, and VH phantoms.

3. 1g SAR in the testes for the VH phantom.

4. The whole-body average SAR for the Eratha, Ella, and VH phantoms.

The maximum radiated power by the signal jammer that guarantees safe exposure for the above measurements, in compliance with the IEEE/ANSI/FCC standard limits, was then calculated at different distances from the human body.

Table 4 lists the computed $1 \mathrm{~g}$ SAR in the head and torso as well as the whole-body averaged SAR in the Eratha phantom due to radiation of simultaneous jammer antennas at 900, 1800, and $2100 \mathrm{MHz}$. The SAR results were normalized to $1 \mathrm{~W} /$ antenna ( $3 \mathrm{~W}$ total power), which represents the real maximum transmission power for the device investigated. Table 5 lists the same computations for the Ella phantom, whereas Table 6 lists the computations in addition to the $1 \mathrm{~g}$ SAR in the testes of the VH phantom. 
Table 4. SAR (W/kg) computation results for Eratha phantom in front of the portable jammer working at 900,1800 , and $2100 \mathrm{MHz}$, simultaneously, normalized to $1 \mathrm{~W} /$ antenna power.

\begin{tabular}{|l|c|c|c|c|c|}
\hline & \multirow{2}{*}{ Frequency } & \multicolumn{4}{|c|}{ Distance } \\
\cline { 2 - 6 } & & $20 \mathrm{~cm}$ & $50 \mathrm{~cm}$ & $100 \mathrm{~cm}$ & $200 \mathrm{~cm}$ \\
\hline \multirow{3}{*}{ g SAR in head (W/kg) } & $900 \mathrm{MHz}$ & $9.90 \times 10^{-2}$ & $2.60 \times 10^{-2}$ & $4.40 \times 10^{-3}$ & $3.50 \times 10^{-6}$ \\
\cline { 2 - 6 } & $1800 \mathrm{MHz}$ & $1.56 \times 10^{-1}$ & $1.10 \times 10^{-2}$ & $2.70 \times 10^{-3}$ & $7.50 \times 10^{-7}$ \\
\cline { 2 - 6 } & $2100 \mathrm{MHz}$ & $3.10 \times 10^{-1}$ & $3.30 \times 10^{-2}$ & $3.80 \times 10^{-3}$ & $2.20 \times 10^{-5}$ \\
\hline \multirow{3}{*}{ 1g SAR in torso (W/kg) } & $900 \mathrm{MHz}$ & $6.10 \times 10^{-2}$ & $1.70 \times 10^{-2}$ & $3.00 \times 10^{-3}$ & $4.80 \times 10^{-7}$ \\
\hline & $1800 \mathrm{MHz}$ & $4.70 \times 10^{-2}$ & $1.40 \times 10^{-2}$ & $2.40 \times 10^{-3}$ & $1.70 \times 10^{-9}$ \\
\hline & $2100 \mathrm{MHz}$ & $8.20 \times 10^{-2}$ & $1.90 \times 10^{-2}$ & $1.60 \times 10^{-3}$ & $4.90 \times 10^{-6}$ \\
\hline \multirow{3}{*}{ Whole-body averaged SAR (W/kg) } & $900 \mathrm{MHz}$ & $1.20 \times 10^{-3}$ & $1.16 \times 10^{-3}$ & $4.40 \times 10^{-4}$ & $6.50 \times 10^{-8}$ \\
\hline & $1800 \mathrm{MHz}$ & $2.50 \times 10^{-3}$ & $1.06 \times 10^{-3}$ & $2.50 \times 10^{-4}$ & $5.50 \times 10^{-9}$ \\
\hline & $2100 \mathrm{MHz}$ & $3.20 \times 10^{-3}$ & $1.41 \times 10^{-3}$ & $3.50 \times 10^{-4}$ & $3.50 \times 10^{-7}$ \\
\hline
\end{tabular}

Table 5. SAR (W/kg) computation results for Ella phantom in front of the portable jammer working at 900,1800 , and $2100 \mathrm{MHz}$, simultaneously, normalized to $1 \mathrm{~W} /$ antenna power.

\begin{tabular}{|l|c|c|c|c|c|}
\hline & \multirow{2}{*}{ Frequency } & \multicolumn{4}{|c|}{ Distance } \\
\cline { 3 - 6 } & & $20 \mathrm{~cm}$ & $50 \mathrm{~cm}$ & $100 \mathrm{~cm}$ & $200 \mathrm{~cm}$ \\
\hline \multirow{3}{*}{ g SAR in head (W/kg) } & $900 \mathrm{MHz}$ & $4.00 \times 10^{-3}$ & $1.75 \times 10^{-2}$ & $6.40 \times 10^{-3}$ & $7.50 \times 10^{-4}$ \\
\cline { 2 - 6 } & $1800 \mathrm{MHz}$ & $6.50 \times 10^{-2}$ & $3.45 \times 10^{-2}$ & $1.62 \times 10^{-3}$ & $5.50 \times 10^{-7}$ \\
\cline { 2 - 6 } & $2100 \mathrm{MHz}$ & $6.00 \times 10^{-2}$ & $5.10 \times 10^{-2}$ & $6.60 \times 10^{-3}$ & $1.30 \times 10^{-6}$ \\
\hline \multirow{3}{*}{ 1g SAR in torso (W/kg) } & $900 \mathrm{MHz}$ & $1.25 \times 10^{-1}$ & $3.50 \times 10^{-2}$ & $1.10 \times 10^{-2}$ & $7.60 \times 10^{-4}$ \\
\cline { 3 - 6 } & $1800 \mathrm{MHz}$ & $5.00 \times 10^{-2}$ & $8.00 \times 10^{-3}$ & $7.50 \times 10^{-4}$ & $8.00 \times 10^{-8}$ \\
\hline \multirow{3}{*}{ Whole-body averaged SAR (W/kg) } & $2100 \mathrm{MHz}$ & $7.50 \times 10^{-2}$ & $1.23 \times 10^{-2}$ & $2.40 \times 10^{-3}$ & $4.00 \times 10^{-7}$ \\
\hline & $900 \mathrm{MHz}$ & $1.88 \times 10^{-3}$ & $9.83 \times 10^{-4}$ & $4.84 \times 10^{-4}$ & $3.29 \times 10^{-5}$ \\
\hline & $1800 \mathrm{MHz}$ & $1.49 \times 10^{-3}$ & $7.00 \times 10^{-4}$ & $5.58 \times 10^{-5}$ & $1.10 \times 10^{-10}$ \\
\hline & $2100 \mathrm{MHz}$ & $1.93 \times 10^{-3}$ & $9.20 \times 10^{-4}$ & $2.60 \times 10^{-4}$ & $4.38 \times 10^{-9}$ \\
\hline
\end{tabular}

Table 6. SAR (W/kg) computation results for VH phantom in front of the portable jammer working at 900 , 1800 , and $2100 \mathrm{MHz}$, simultaneously, normalized to $1 \mathrm{~W} /$ antenna power.

\begin{tabular}{|c|c|c|c|c|c|}
\hline & \multirow{2}{*}{ Frequency } & \multicolumn{4}{|c|}{ Distance } \\
\hline & & $20 \mathrm{~cm}$ & $50 \mathrm{~cm}$ & $100 \mathrm{~cm}$ & $200 \mathrm{~cm}$ \\
\hline \multirow{3}{*}{ 1g SAR in head $(W / k g)$} & $900 \mathrm{MHz}$ & $4.62 \times 10^{-3}$ & $5.20 \times 10^{-3}$ & $3.26 \times 10^{-3}$ & $9.60 \times 10^{-4}$ \\
\hline & $1800 \mathrm{MHz}$ & $1.05 \times 10^{-2}$ & $1.85 \times 10^{-2}$ & $3.52 \times 10^{-3}$ & $3.50 \times 10^{-7}$ \\
\hline & $2100 \mathrm{MHz}$ & $3.00 \times 10^{-3}$ & $3.00 \times 10^{-2}$ & $1.47 \times 10^{-2}$ & $1.80 \times 10^{-6}$ \\
\hline \multirow{3}{*}{ 1g SAR in torso $(\mathrm{W} / \mathrm{kg})$} & $900 \mathrm{MHz}$ & $4.98 \times 10^{-2}$ & $1.22 \times 10^{-2}$ & $3.80 \times 10^{-3}$ & $7.00 \times 10^{-4}$ \\
\hline & $1800 \mathrm{MHz}$ & $4.16 \times 10^{-2}$ & $8.40 \times 10^{-3}$ & $7.20 \times 10^{-4}$ & $3.30 \times 10^{-6}$ \\
\hline & $2100 \mathrm{MHz}$ & $5.21 \times 10^{-2}$ & $1.13 \times 10^{-2}$ & $3.25 \times 10^{-3}$ & $1.50 \times 10^{-5}$ \\
\hline \multirow{3}{*}{ 1g SAR in testes $(\mathrm{W} / \mathrm{kg})$} & $900 \mathrm{MHz}$ & $2.31 \times 10^{-2}$ & $1.80 \times 10^{-2}$ & $7.40 \times 10^{-3}$ & $1.30 \times 10^{-3}$ \\
\hline & $1800 \mathrm{MHz}$ & $8.05 \times 10^{-2}$ & $3.10 \times 10^{-2}$ & $2.40 \times 10^{-3}$ & $2.20 \times 10^{-7}$ \\
\hline & $2100 \mathrm{MHz}$ & $1.08 \times 10^{-1}$ & $3.60 \times 10^{-2}$ & $3.30 \times 10^{-3}$ & $3.30 \times 10^{-6}$ \\
\hline \multirow{3}{*}{ Whole-body averaged SAR (W/kg) } & $900 \mathrm{MHz}$ & $1.20 \times 10^{-3}$ & $6.00 \times 10^{-4}$ & $2.73 \times 10^{-4}$ & $4.96 \times 10^{-5}$ \\
\hline & $1800 \mathrm{MHz}$ & $1.24 \times 10^{-3}$ & $5.00 \times 10^{-4}$ & $4.35 \times 10^{-5}$ & $8.37 \times 10^{-8}$ \\
\hline & $2100 \mathrm{MHz}$ & $1.00 \times 10^{-3}$ & $6.03 \times 10^{-4}$ & $1.59 \times 10^{-4}$ & $1.68 \times 10^{-7}$ \\
\hline
\end{tabular}


The results in Tables 4, 5, and 6 reveal the following:

1. The induced $1 \mathrm{~g}$ SAR in the head and torso as well as the whole-body averaged SAR are inversely dependent on distance. The SAR decreases dramatically as the distance from the jammer increases but is negligible at $200 \mathrm{~cm}$.

2. The induced $1 \mathrm{~g}$ SAR in the head and torso depends on the head and torso height with respect to the jammer level. The Eratha phantom showed more induced $1 \mathrm{~g}$ SAR in the head than the Ella and VH phantoms owing to the head position, which is in front of the jammer, and both have almost the same height compared to the other two phantoms. The same scenario is applicable for the torso tissue, where the Ella phantom exhibited greater induced 1g SAR.

3. The induced $1 \mathrm{~g}$ SAR showed no effect due to phantom size; however, the height differences between the jammer and the heads were important.

4. For distances $<100 \mathrm{~cm}$ away from the signal jammer, the Eratha phantom showed a larger average SAR over the whole body but smaller values at distances $\geq 100 \mathrm{~cm}$ compared to the Ella and VH phantoms.

Table 7 lists the 1g SAR induced in the head and torso as well as the whole-body averaged SAR due to the combined local SAR of the three jammers' antennas at 900, 1800, and $2100 \mathrm{MHz}$, simultaneously. The SEMCAD X®-based computed combined 1g SAR and the combined whole-body averaged SAR values coincide with the rules given in section 5 
Table 7. Total SAR (W/kg) induced in the Eratha, Ella, and VH phantoms due to the combined SAR of the jammer antenna radiations at 900,1800 , and $2100 \mathrm{MHz}$, normalized to $1 \mathrm{~W} /$ antenna power, and percentage level of exposure according to allowable limits of the IEEE/ANSI/FCC standard.

\begin{tabular}{|c|c|c|c|c|c|}
\hline & \multicolumn{4}{|c|}{ Distance } \\
\hline & & $20 \mathrm{~cm}$ & $50 \mathrm{~cm}$ & $100 \mathrm{~cm}$ & $200 \mathrm{~cm}$ \\
\hline \multirow{3}{*}{ Eratha } & $\begin{array}{l}\text { Total 1g SAR in head }(\mathrm{W} / \mathrm{kg}) \\
\text { (\% level of exposure) }\end{array}$ & $\begin{array}{l}5.63 \times 10^{-1} \\
(35.2 \%)\end{array}$ & $\begin{array}{l}6.71 \times 10^{-2} \\
(4.2 \%)\end{array}$ & $\begin{array}{c}1.09 \times 10^{-2} \\
(0.7 \%)\end{array}$ & $\begin{array}{c}2.48 \times 10^{-5} \\
(0.00 \%)\end{array}$ \\
\hline & $\begin{array}{l}\text { Total } 1 \mathrm{~g} \text { SAR in torso }(\mathrm{W} / \mathrm{kg}) \\
\text { (\% level of exposure) }\end{array}$ & $\begin{array}{c}1.41 \times 10^{-1} \\
(8.8 \%)\end{array}$ & $\begin{array}{l}3.52 \times 10^{-2} \\
(2.2 \%)\end{array}$ & $\begin{array}{c}4.80 \times 10^{-3} \\
(0.3 \%)\end{array}$ & $\begin{array}{l}5.29 \times 10^{-7} \\
(0.00 \%)\end{array}$ \\
\hline & $\begin{array}{l}\text { Total whole-body averaged SAR }(\mathrm{W} / \mathrm{kg}) \\
\text { (\% level of exposure) }\end{array}$ & $\begin{array}{c}6.90 \times 10^{-3} \\
(8.6 \%)\end{array}$ & $\begin{array}{c}3.63 \times 10^{-3} \\
(4.5 \%)\end{array}$ & $\begin{array}{c}1.04 \times 10^{-3} \\
(1.3 \%)\end{array}$ & $\begin{array}{r}4.21 \times 10^{-8} \\
(0.00 \%)\end{array}$ \\
\hline \multirow{3}{*}{ Ella } & $\begin{array}{l}\text { Total } 1 \mathrm{~g} \mathrm{SAR} \text { in head }(\mathrm{W} / \mathrm{kg}) \\
\text { (\% level of exposure) }\end{array}$ & $\begin{array}{c}1.29 \times 10^{-1} \\
(8.1 \%)\end{array}$ & $\begin{array}{c}8.58 \times 10^{-2} \\
(5.4 \%)\end{array}$ & $\begin{array}{c}1.44 \times 10^{-2} \\
(0.9 \%)\end{array}$ & $\begin{array}{c}7.50 \times 10^{-4} \\
(0.05 \%)\end{array}$ \\
\hline & $\begin{array}{l}\text { Total } 1 \mathrm{~g} \text { SAR in torso }(\mathrm{W} / \mathrm{kg}) \\
\text { (\% level of exposure) }\end{array}$ & $\begin{array}{l}1.37 \times 10^{-1} \\
(8.6 \%)\end{array}$ & $\begin{array}{l}3.75 \times 10^{-2} \\
(2.3 \%)\end{array}$ & $\begin{array}{c}1.10 \times 10^{-2} \\
(0.7 \%)\end{array}$ & $\begin{array}{l}7.60 \times 10^{-4} \\
(0.05 \%)\end{array}$ \\
\hline & $\begin{array}{l}\text { Total whole-body averaged SAR }(\mathrm{W} / \mathrm{kg}) \\
\text { (\% level of exposure) }\end{array}$ & $\begin{array}{l}5.29 \times 10^{-3} \\
(6.6 \%)\end{array}$ & $\begin{array}{c}2.60 \times 10^{-3} \\
(3.3 \%)\end{array}$ & $\begin{array}{c}8.00 \times 10^{-4} \\
(1.0 \%)\end{array}$ & $\begin{array}{r}3.29 \times 10^{-5} \\
(0.04 \%)\end{array}$ \\
\hline \multirow{4}{*}{ VH } & $\begin{array}{l}\text { Total } 1 \mathrm{~g} \text { SAR in head }(\mathrm{W} / \mathrm{kg}) \\
\text { (\% level of exposure) }\end{array}$ & $\begin{array}{c}1.62 \times 10^{-2} \\
(1.0 \%)\end{array}$ & $\begin{array}{c}5.10 \times 10^{-2} \\
(3.2 \%)\end{array}$ & $\begin{array}{c}2.00 \times 10^{-2} \\
(1.3 \%)\end{array}$ & $\begin{array}{c}1.10 \times 10^{-3} \\
(0.07 \%)\end{array}$ \\
\hline & $\begin{array}{l}\text { Total 1g SAR in torso }(\mathrm{W} / \mathrm{kg}) \\
\text { (\% level of exposure) }\end{array}$ & $\begin{array}{c}1.21 \times 10^{-1} \\
(7.6 \%)\end{array}$ & $\begin{array}{c}2.33 \times 10^{-2} \\
(1.5 \%)\end{array}$ & $\begin{array}{c}6.40 \times 10^{-3} \\
(0.4 \%)\end{array}$ & $\begin{array}{c}7.10 \times 10^{-4} \\
(0.04 \%)\end{array}$ \\
\hline & $\begin{array}{l}\text { Total } 1 \mathrm{~g} \text { SAR in testes }(\mathrm{W} / \mathrm{kg}) \\
\text { (\% level of exposure) }\end{array}$ & $\begin{array}{l}1.93 \times 10^{-1} \\
(12.1 \%)\end{array}$ & $\begin{array}{l}7.50 \times 10^{-2} \\
(4.7 \%)\end{array}$ & $\begin{array}{c}1.10 \times 10^{-2} \\
(0.7 \%)\end{array}$ & $\begin{array}{l}1.30 \times 10^{-3} \\
(0.08 \%)\end{array}$ \\
\hline & $\begin{array}{l}\text { Total whole-body averaged SAR }(\mathrm{W} / \mathrm{kg}) \\
\text { (\% level of exposure) }\end{array}$ & $\begin{array}{c}3.44 \times 10^{-3} \\
(4.3 \%)\end{array}$ & $\begin{array}{c}1.70 \times 10^{-3} \\
(2.1 \%)\end{array}$ & $\begin{array}{c}4.75 \times 10^{-4} \\
(0.6 \%)\end{array}$ & $\begin{array}{r}4.98 \times 10^{-5} \\
(0.06 \%)\end{array}$ \\
\hline
\end{tabular}

In Table 7, the percentage level of exposure values, according to the allowable limits of the IEEE/ANSI/FCC standard, were found by dividing the $1 \mathrm{~g}$ SAR in the head and torso by 1.6 and the whole-body averaged SAR by 0.08 .

Based on the results in Table 7 and according to the limits of the IEEE/ANSI/FCC standard given in Table 1, Table 8 shows the maximum allowed radiated power of the jammer device for Eratha, Ella, VH, and general human safe exposure with respect to distance. Table 8 is useful to give an indication of the maximum allowed radiated power of other jammer geometries for safe exposure according to the limits of the IEEE/ANSI/FCC standard. It is obvious that the Eratha phantom was affected more than the other two phantoms by the jammer antenna radiation. 
Table 8. Maximum allowed radiated power (W) of the jammer device working at 900,1800 and $2100 \mathrm{MHz}$, simultaneously, in front of Eratha, Ella and VH phantoms for safe exposure according to IEEE/ANSI/FCC standard.

\begin{tabular}{|c|c|c|c|c|c|}
\hline & \multicolumn{4}{|c|}{ Distance } \\
\hline & & $20-\mathrm{cm}$ & $50-\mathrm{cm}$ & $100-\mathrm{cm}$ & $200-\mathrm{cm}$ \\
\hline \multirow{4}{*}{ Eratha } & Max. total output power for safe head tissue exposure & 8.4 & 71.4 & 440.4 & 193548 \\
\hline & Max. total output power for safe torso tissue exposure & 33.9 & 136.5 & 999.9 & 90735 \\
\hline & Max. total output power for safe whole-body average exposure & 34.8 & 66 & 230.7 & 570750 \\
\hline & Max. total output power for general safe exposure & 8.4 & 66 & 230.7 & 193548 \\
\hline \multirow{4}{*}{ Ella } & Max. total output power for safe head tissue exposure & 37.2 & 55.8 & 333.3 & 6399 \\
\hline & Max. total output power for safe torso tissue exposure & 35.1 & 128.1 & 436.5 & 6315 \\
\hline & Max. total output power for safe whole-body average exposure & 45.3 & 92.1 & 300 & 7284 \\
\hline & Max. total output power for general safe exposure & 35.1 & 55.8 & 300 & 6315 \\
\hline \multirow{5}{*}{$\mathrm{VH}$} & Max. total output power for safe head tissue exposure & 296.4 & 94.2 & 240 & 4365 \\
\hline & Max. total output power for safe torso tissue exposure & 39.6 & 206.1 & 750 & 6762 \\
\hline & Max. total output power for safe testes tissue exposure & 24.9 & 63.9 & 436.5 & 3693 \\
\hline & Max. total output power for safe whole-body average exposure & 69.9 & 141 & 504.9 & 4815 \\
\hline & Max. total output power for general safe exposure & 24.9 & 63.9 & 240 & 3693 \\
\hline \multicolumn{2}{|r|}{ Maximum allowed total output power for general human safe exposure } & 8.4 & 55.8 & 230.7 & 3693 \\
\hline
\end{tabular}

It is obvious in Table 8 that using the portable jammer with 3-4 W maximum output power in front of the human body will comply with the safety limits of the IEEE/ANSI/FCC standard, whereas using the desktop jammers with total output power in the range of 60-70 W will comply with safety limits at distances greater than $50 \mathrm{~cm}$.

Fig. 7 shows the 1g SAR surface/peak-slice distribution over the Eratha, Ella, and VH bodies due to the combined local SAR of the three antennas, simultaneously, at different distances from the signal jammer 


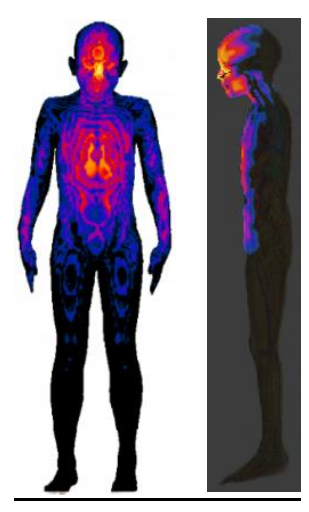

$20 \mathrm{~cm}$

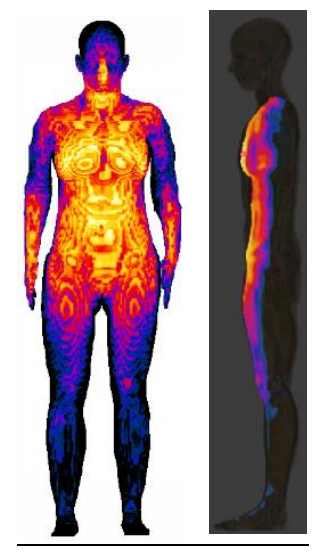

$20 \mathrm{~cm}$

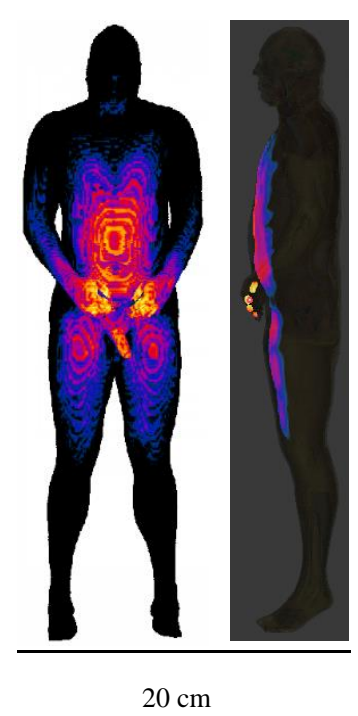

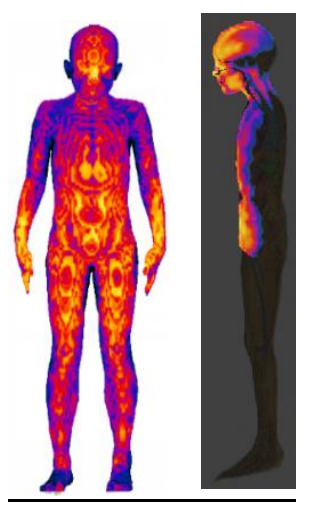

$50 \mathrm{~cm}$

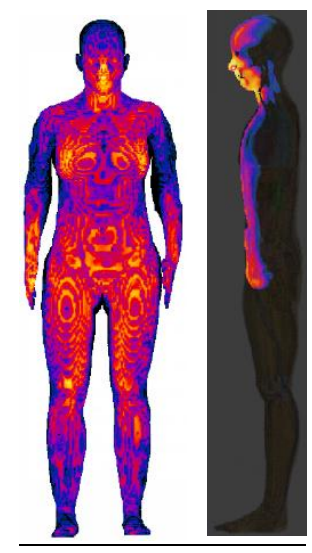

$50 \mathrm{~cm}$

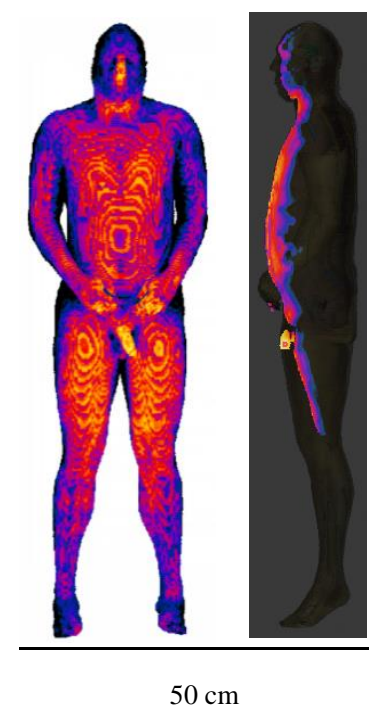

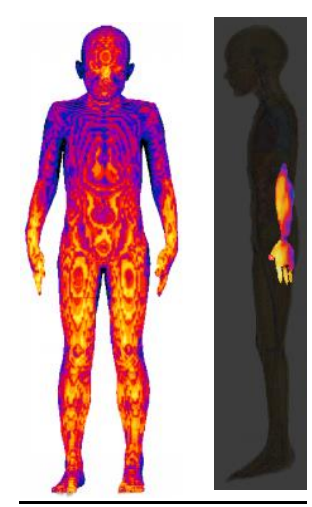

$100 \mathrm{~cm}$

(a)

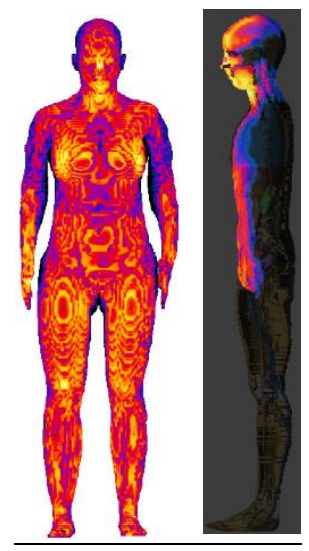

$100 \mathrm{~cm}$

(b)

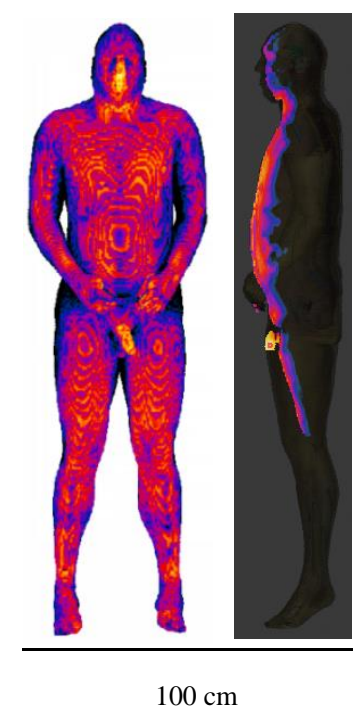

(c)

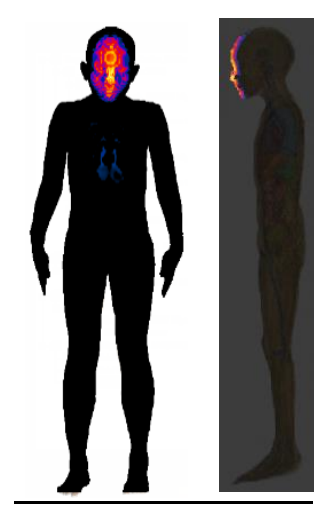

$200 \mathrm{~cm}$

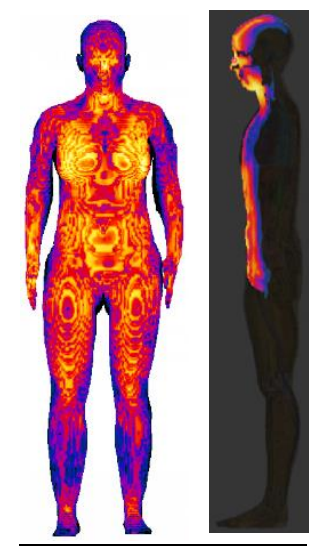

$200 \mathrm{~cm}$

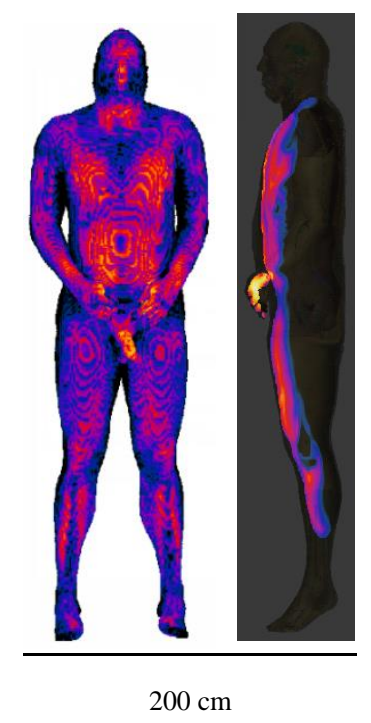

$\begin{array}{lll}0 & -4 & -8\end{array}$

$-12$ $-16-20 \mathrm{~dB}$

Fig. 7. 1g SAR Surface/ peak-slice distributions for (a) Eratha phantom, (b) Ella phantom, and (c) VH phantom, at different distances from the portable jammer. 


\section{CONCLUSION}

This paper achieved the numerical dosimetry of a mobile phone signal jammer with high-resolution FDTD gridding. A commercially available portable mobile phone signal jammer working with three antennas and covering the bands CDMA/GSM, DCS/PCS, and 3G was numerically modelled. The peak spatial-average SAR over $1 \mathrm{~g}$ induced in the head and torso as well as the whole-body averaged SAR of three anatomical human body phantoms of different ages and genders exposed to the EM jammer radiation were computed at different distances.

Based on the adopted scenarios of the numerical dosimetry, the achieved results revealed that using the portable mobile phone signal jammer is safe and complies with the safety limits of the IEEE/ANSI/FCC standard, whereas a human body at a distance of more than $50 \mathrm{~cm}$ will be kept away from the EM hazard of a desktop signal jammer.

\section{ACKNOWLEDGMENT}

The authors would like to thank Mr. Guillermo Del Castillo from SPEAG Schmid \& Partner Engineering AG, Zurich, Switzerland, for his technical support during installing the SEMCAD X® on the hp® Z420 and setting the Tesla GPU® K20.

\section{REFERENCES}

1. Jensen, M.A., Rahmat-Samii, Y.: 'EM interaction of handset antennas and a human in personal communications', Proc. of the IEEE, 1995, 83, (1), pp. 7-17

2. Watanabe, S., Taki, M., Nojima, T., et al.: 'Characteristics of the SAR distributions in a head exposed to electromagnetic fields radiated by a hand-held portable radio', IEEE Transactions on Microwave Theory and Techniques, 1996, 44, (10), pp. 1874-1883

3. Okoniewski, M., Stuchly, M.A.: 'A study of the handset antenna and human body interaction', IEEE Transactions on Microwave Theory and Techniques, 1996, 44, (10), pp. 1855-1864 
4. Wang, J., Fujiwara, O.: 'Dosimetric evaluation of human head for portable telephones', Electronics and Communications in Japan, Part I, 2002, 85, (7), pp. 12-22

5. Martinez-Burdalo, M., Martin, A., Anguiano, M., et al.: 'Comparison of FDTD-calculated specific absorption rate in adults and children when using a mobile phone at 900 and $1800 \mathrm{MHz}$, Physics in Medicine and Biology, 2004, 49, (2), pp. 345-354

6. Beard, B.B., Kainz, W., Onishi, T., et al.: 'Comparisons of computed mobile phone induced SAR in the SAM phantom to that in anatomically correct models of the human head', IEEE Transactions on Electromagnetic Compatibility, 2006, 48, (2), pp. 397-407

7. Al-Mously, S.I., Abousetta, M.M.: 'Anticipated Impact of Hand-Hold Position on the Electromagnetic Interaction of Different Antenna Types/Positions and a Human in Cellular Communications', International Journal of Antennas and Propagation (IJAP), 2008, Article ID 102759, 22 pages, doi:10.1155/2008/102759

8. Sabbah, A.I., Dib, N.I., Al-Nimr, M.A.: 'Evaluation of specific absorption rate and temperature elevation in a multi-layered human head model exposed to radio frequency radiation using the finitedifference time domain method', IET Microwaves, Antennas \& Propagation, 2011, 5, (9), pp. 10731080

9. Kuehn, S., Kelsh, M.A., Kuster, N., et al.: 'Analysis of mobile phone design features affecting radiofrequency power absorbed in a human head phantom', Bioelectromagnetics, 2013, 34, (6), pp. $479-488$

10. IT'IS Foundation, 'Development of Procedures for the Assessment of Human Exposure to EMF from Wireless Devices in Home and Office Environments', (ETH Zurich, 2005)

11. ANSI/IEEE: 'Std. C.95.1: Safety levels with respect to human exposure to radiofrequency electromagnetic fields. $3 \mathrm{KHz}$ to $300 \mathrm{GHz}, 1992$

12. ICNIRP, 'Guidelines for limiting exposure to time-varying electric, magnetic, and electromagnetic fields (up to $300 \mathrm{GHz}$ )', Health Phys., 1998, 74, (4), pp. 494-522 
13. European Committee for Electrical Standardization (CENELEC): 'EN 50360: Product standard to demonstrate the compliance of mobile phones with the basic restrictions related to human exposure to electromagnetic fields (300 MHz-3 GHz)', 2001

14. Australian Communications Authority (ACA) Radio Communications: 'Electromagnetic Radiation Human Exposure', 2003

15. ARIB STD-T56: 'Specific Absorption Rate (SAR) Estimation for Cellular Phone, Association of Radio Industries and businesses', 2002

16. 'International Telecommunication Union, Switzerland, Geneva', http://www.itu.int, accessed April 2014

17. 'IEEE 802.15 Working Group for WPAN', http://www.ieee802.org/15/, accessed May 2014

18. 'Official IEEE 802.11 working group project timelines', http://www.ieee802.org/11/, accessed May 2014

19. 'WiMAX Forum Overview, retrieved on 2008-03-01', http://www.wimaxforum.org, accessed May 2014

20. 'CTS Technology Co Ltd.', http://ctstechnologys.com/, accessed January 2014

21. Poisel, R.A.: 'Modern Communications Jamming Principles and Techniques', Artech House Inc., 2004

22. 'Jammer Tip Line, FCC', http://www.fcc.gov/encyclopedia/jammer-enforcement, accessed February 2014

23. Australian Government, ComLaw: 'Notification that the Australian Communications and Media Authority prohibits the operation or supply, or possession for the purpose of operation or supply, of specified devices', http://www.comlaw.gov.au/Series/F2005B00449, accessed February 2014

24. 'Justice Law Website, Canada', http://laws-lois.justice.gc.ca/eng/acts/R-2/FullText.html, accessed February 2014 
25. 'Post and Telecom Authority (PTS), Sweden', http://www.pts.se/sv/Privat/Radio/Utrustning/Forbudmot-storsandare/, accessed February 2014

26. 'Prisons (Interference with Wireless Telegraphy) Act 2012', http://services.parliament.uk/bills/201213/prisonsinterferencewithwirelesstelegraphy.html, accessed February 2014

27. Zhang, Z.: ‘Antenna Design for Mobile Devices’ (Wiley-IEEE Press, 2011, 1st edn.)

28. Yee, K.S.: 'Numerical solution of initial boundary value problems involving Maxwell's equations in isotropic media', IEEE Transactions on Antennas and Propagation, 1966, 14, (3), pp. 302-307

29. Schneide, J.B.: 'Understanding the FDTD method', December 6, 2010. Available at http://www.eecs.wsu.edu/ schneidj/ufdtd/, accessed May 2014

30. SEMCAD-X, 20014. Version 14.8 Altesch. Reference Manual, Simulation Platform for Electromagnetic Compatibility, Antenna Design and Dosimetry, SPEAG - Schmid \& Partner Engineering AG: http://www.semcad.com, accessed January 2014

31. 'Hewlett-Packard workstations', http://www8.hp.com/us/en/campaigns/workstations/z420.html, accessed January 2014

32. 'PNY Technologies', http://www.pny.eu/product/p-8-70-596/NVIDIA-Tesla/Tesla-K20-Card/, accessed January 2014

33. Rowell, C., Lam, E.Y.: 'Mobile-Phone Antenna Design', IEEE Antennas Propagation Magazine, 2012, 54, (4), pp. 14-34

34. Anguera, J., Andújar, A., Huynh, M.C., et al.: 'Advances in Antenna Technology for Wireless Handheld Devices', International Journal on Antennas and Propagation, 2013, Article ID 838364, 25 pages, 2013. doi:10.1155/2013/838364

35. Orlenius, C., Serafimov, N., Kildal, P.-S.: 'Procedure for measuring radiation efficiency in downlink band for active mobile phones in a reverberation chamber', Proc. of the IEEE Antennas and Propagation Society International Symposium, Columbus, Ohio, USA, June 2003, 4, pp. 731-734 
36. Orlenius, C., Kildal, P.-S., and Poilasne, G.: 'Measurements of total isotropic sensitivity and average fading sensitivity of CDMA phones in reverberation chamber', Proc. of the IEEE Antennas and Propagation Society International Symposium, 1A, Washington, DC, USA, July 2005, pp. 409-412

37. CTIA Certification, 'Test Plan for Mobile Station Over the Air Performance: Method of Measurement for Radiated RF Power and Receiver Performance', Revision 2.1, April 2005.

38. Grisso, R.B., Mark, A.W.G., Holshouser, D., et al.: 'Precision farming tools: soil electrical conductivity', 2007, Virginia Cooperative Extension, Virginia State University, pp. 442-508

39. Thiel, M., Sarabandi, K.: '3D-wave propagation analysis of indoor wireless channels utilizing hybrid methods', IEEE Transactions on Antennas and Propagation, 2009, 57, (5), pp. 1539-1546

40. Dimbylow, P.J., Gandhi, O.P.: 'Finite-difference time-domain calculations of SAR in a realistic heterogeneous model of the head for plane-wave exposure from $600 \mathrm{MHz}$ to $3 \mathrm{GHz}$, Physics in Medicine and Biology, 1991, 36, (8), pp. 1075-1089

41. Whittow, W., Panagamuwa, C., Derat, B., et al.: 'Correlation of specific absorption rates in the human head due to multiple independent sources', Proc. Int. Conf. Antennas \& Propagation, LAPC 2009, Loughborough, UK, Nov. 2009, pp. 405-408. 